IOS Press

\title{
Anthropometric aspects of body seated in school
}

\author{
Reis, P. ${ }^{\mathrm{a}, \mathrm{b}^{*}}$; Moro, A. R. ${ }^{\mathrm{a}, \mathrm{de}}$, Da Silva, J. ${ }^{\mathrm{f}}$; Paschoarelli, L. ${ }^{\mathrm{f}}$; Nunes Sobrinho, F. ${ }^{\mathrm{g}}$ and Peres, L. ${ }^{\mathrm{c}}$ \\ ${ }^{a}$ Graduate Program in Production Engineering, Federal University of Santa Catarina, SC, Brazil \\ ${ }^{b}$ Community College of Foz do Iguaçu, PR, Brazil \\ ${ }^{c}$ Departament of Physical Education, University of West Paraná, PR, Brazil \\ ${ }^{d}$ Department of Physical Education, Federal University of Santa Catarina, SC, Brazil \\ ${ }^{e}$ Graduate Program in Physical Education, Federal University of Santa Catarina, SC, Brazil \\ ${ }^{f}$ State University of São Paulo \\ ${ }^{g}$ Federal University of Rio de Janeiro
}

\begin{abstract}
This study aimed to assess the student-furniture interface from anthropometric parameters of the sitting posture. The sample was composed of 887 students from two public schools in the State of Parana - Brazil, which attended children from 7 to 17 years of age. The data collection used anthropometric measures of the sitting position, a questionnaire containing a human body diagram for indication of discomfort areas and photographic records to verify postural and ergonomic inadequacies in classroom. The following anthropometric variables were measured: popliteal height, sacro-popliteal length, hip width, lumbar support height, and elbow and thigh height. Percentiles 5 and 95 of anthropometric variables showed differences statistically significant, with variation coefficient greater than $30 \%$. In relation to body discomfort, the highest occurrences were recorded for ankle, knees and shoulder joints as well as for spine and buttocks. It was concluded that children use school furniture that does not meet their anthropometric standards, which favored the adoption of incorrect postures and contributed to the emergence of musculoskeletal problems that can interfere with their educational process.
\end{abstract}

Keywords: Seating posture, Discomfort, School furniture

\section{Introduction}

Worldwide, school furniture has always been present in schools as a fundamental element for the performance of school activities; however, little attention has been given to the ergonomic issues in its interaction with users. Despite the growing concern with posture problems in schools, children still use inadequate furniture, especially regarding its dimensioning. This undoubtedly will corroborate the later appearance of several orthopedic problems, and will also interfere with the educational process of students $[14,15,17,20,22-26,30,33,35,37,44]$.

Educational tasks that occur within the classroom environment such as reading, writing, interpreting and viewing require a high audition, motor and cognitive concentration, which makes it important that the furniture has ergonomic design and size compati- ble to users. All students must remain seated in a balanced posture, without great biomechanical effort, thereby reducing the muscle fatigue levels and favoring the performance of school activities, with consequent improvement of such activities [18,35,36,49].

Misfit school furniture represents a potential factor for the development of postural bad habits in the sitting position and in the performance of school activities, which may cause motor and orthopedic changes for life. In the school period (including growth and body formation), every biomechanical requirement such as compression, tension, tilt and twist forces on the musculoskeletal system will define the postural configuration of the future adult, thus, erroneous stimuli are responsible for significant skeletal deformities, especially those arising from the seated position with the use of unsuitable furniture $[4,9,14,30,35,36,38,47]$.

\footnotetext{
* Corresponding author: Pedro Ferreira Reis, Instituto de Ensino Superior de Foz do Iguaçu, Universidade Federal de Santa Catarina Programa de Pós Graduação em Engenharia de Produção - Ergonomia - Laboratório de Biomecânica - Campus Universitário, Trindade, Florianópolis, SC, Brazil. CEP:88040-970; Tel. (55)4837218530; E-mail: ergoreis@hotmail.com
} 
Ergonomics must be present in all sectors where there is human presence, and must be aimed to provide the greatest fitness and comfort as possible in the development of their activities, whether in work, leisure and daily activities [16]. However, studies on school furniture design and its effects on posture and on the development of schoolchildren are very recent and scarce. Researchers acknowledge that it is in school, where children remain seated most of the time, that the majority of disagreements between research results and their actual use occur $[1,3,10,13,16,21,31,39,46,48]$.

School furniture is undoubtedly an essential element and vital in the educational process, since it is responsible for the physical and psychological comfort of students, encouraging their learning and, therefore, it must be appropriate to users and pedagogical needs of schools [20,25,26,35,36,38,39].

The use of inadequate furniture affects the comfort of users. Thus, desks whose design does not meet the biotype of students will affect their school performance by exposing them to embarrassing situations in the development of activities in the sitting position. These disagreements of ergonomic nature resulting from the disharmony between the subject and its interface will contribute to the emergence of diseases in the vertebral column of children because they are in the growth phase $[14,48]$. Likewise, children and adolescents with frequent symptoms of pain / body discomfort will not be interested in acquiring the contents, since their concentration and willingness to learn will be impaired $[11,28,43]$.

Providing furniture suitable to humans and their working environment, mainly for children, who are more likely to acquire postural problems such as kyphosis, lordosis and scoliosis [23,34] is a duty of organizations. Only with proper use, health problems can be avoided, especially at school age, which is the phase of body growth. With advancing age, obtaining results in terms of postural correction becomes more difficult, because bone growth becomes increasingly defined [9,17,27].

During the growth phase, the body segment grows faster than the head, followed by the trunk and, after six years of age, lower limbs grow more significantly, continuing to grow faster than other body segments until the onset of puberty, which, in turn, trunk grows faster again. This indicates that at the different school phases until the beginning of puberty, one should pay more attention to the height of the seat and, during the puberty, the height of the desk deserves more attention $[40,45]$.
In this context, this work aimed to study the in student-furniture interaction according to anthropometric and biomechanical parameters at the sitting position, as well as to show discrepancies between standard recommendations and their practical applications.

\section{Method}

\subsection{Participants}

Eight-hundred students enrolled in two public schools participated as the study sample (Tia Anastacia Elementary School and Monteiro Lobato Highschool) in the city of Dois Vizinhos, state of Parana, Brazil. These schoolchildren were children and adolescents from 7 to 17 years of age from different grades and who used, indiscriminately, the same furniture for the performance of their school activities. For the participation of students in the study, permission was requested from parents and / or guardians through an informed consent form approved by the local research ethics committee.

\subsection{Instruments}

To conduct the survey of demographic data, a measurement desk based on the proposal of Serrano was constructed [39]. At the moment of collections, students remained in school uniform consisting of jacket, shirt and sneakers. In addition to collection of anthropometric data, a questionnaire containing a human body diagram $[35,36]$ was applied to register body discomfort complaints and a series of photographic records to identify postural restrictions and inadequacies of biomechanical and ergonomic nature.

The following anthropometric variables were obtained: popliteal height, sacro-popliteal length, hip width, lumbar support height, and elbow and thigh height (Figure 1). Later, the data obtained were compared with the dimensional characteristics of the school furniture used by schools with the anthropometrical characteristics of students grouped by age and the postural demands of reading and writing activities in classroom. 


\subsection{Data analysis}

Descriptive statistics was performed to verify average and standard deviation of the sitting posture (Figure 1), using the Excel for windows software.

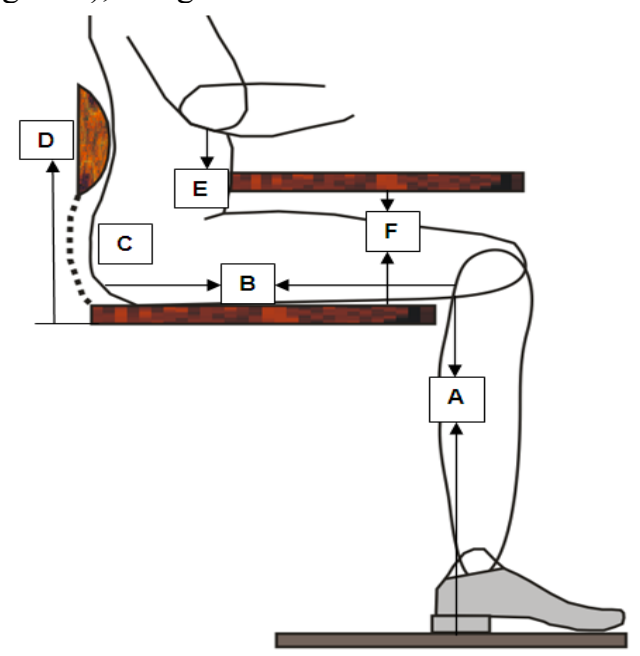

Fig. 1

Anthropometric parameters of the sitting posture used in the study with students aged 7 to 17 years Legend: Popliteal Height (A), Sacro-popliteal Length (B), Hip Width (C), Lumbar Support Height (D), Elbow Height (E), Thigh Height (F).

\section{Results and discussion}

\subsection{Dados antropométricos}

Table 1 shows the means of anthropometric variables and standard deviation related to variables popliteal height, sacro-popliteal length, hip width, lumbar support height, elbow and thigh height, according to the respective age groups of children assessed in the survey.

The data provide a broad idea of the influence of age and growth on anthropometric variables, which are directly involved in the design and dimensioning of school furniture.

The anthropometric values of all variables assessed in the study increased progressively following the 11 age groups. However, these dimensional growths cannot be considered as linear, because in some age groups, the values increased more significant in some variables, such as the popliteal height among children of 9 and 10 years, which increased by $5.52 \mathrm{~cm}$..
The average difference between the lowest and highest difference found was $21.82 \mathrm{~cm}$ for popliteal height; of $20.28 \mathrm{~cm}$ for sacro-popliteal length; of $15.97 \mathrm{~cm}$ for hip width, of $6.91 \mathrm{~cm}$ for thigh height, of $7.15 \mathrm{~cm}$ for the lumbar support height and of $29.66 \mathrm{~cm}$ for elbow height, respectively.

Children with lower heights and lengths were represented by percentile 5 and those with the highest anthropometric measurements by percentile 95. In both groups, the data showed a statistically significant difference with variation coefficient greater than $30 \%$. These data demonstrate that the only type of chair-desk furniture used by both schools does not have the recommended dimensions for the needs of most students.

Assessing the behavior of variable popliteal height, it was observed that the age group from 7 to 10 years showed the smallest and largest popliteal heights, with variations from $26 \mathrm{~cm}$ (7-year-old children) to $40 \mathrm{~cm}$ (10-year-old children), shown by percentiles 5 and 95 , with average value of $30.47 \mathrm{~cm}$ for 7-yearold children and $37.43 \mathrm{~cm}$ for those aged 10 years. It was found that children younger than 9 years of age showed no significant variations in the popliteal height; however, from the age of 10 years, a higher average growth of this variable was identified [45].

From the age of 11 to 14 years, the popliteal height for males ranged from $39 \mathrm{~cm}$ to $50 \mathrm{~cm}$, differing by $11 \mathrm{~cm}$ according to percentiles 5 and 95 . At this age group, the average ranged from $42.63 \mathrm{~cm}$ to 47.61 $\mathrm{cm}$, with an average growth of $4.98 \mathrm{~cm}$. Thus, at this stage, the popliteal height had its best performance in terms of growth, coinciding with the so-called growth spurt $[35,36,45]$. However, the age from 15 to 17 years did not show such growth as in the previous phase, where the lowest and highest percentiles ranged from $46 \mathrm{~cm}$ to $57 \mathrm{~cm}$, and the mean values from $45.62 \mathrm{~cm}$ to $46.84 \mathrm{~cm}$, respectively.

The popliteal height has an important participation in defining the seat height for the respective age groups $[25,26,35,36]$. However, as previously mentioned, the seats used by schools are too high for most of their users, especially regarding percentile 5 . On the other hand, for schoolchildren aged between 15 to 17 years, the seat becomes too low, especially for users of percentile 95. In this case, with the seat height being below recommended levels, the user should be induced to sit a little more curved forward, favoring an increase in intradiscal pressure and the muscle-ligament tension of the spine [4,26]. Although, mathematically, no age range will adapt to a standard furniture height, in this case, the values found for the age range from 11 to 13 years was 
those that most corresponded to the desk used (46

$\mathrm{cm})$.

Table 1

Mean and standard deviation of anthropometric measurements of sitting posture of schoolchildren aged 7 to 17 years from public schools of the city of Dois Vizinhos, state of Parana, Brazil.

\begin{tabular}{ccccccccccccc}
\hline \hline & $\begin{array}{c}\text { Poplíteal height } \\
\text { (cm) }\end{array}$ & $\begin{array}{c}\text { Sacro-poplíteal } \\
\text { length (cm) }\end{array}$ & $\begin{array}{c}\text { Width of the hip } \\
\text { (cm) }\end{array}$ & $\begin{array}{c}\text { Height of the } \\
\text { thigh (cm) }\end{array}$ & $\begin{array}{c}\text { Height lumbar } \\
\text { support(cm) }\end{array}$ & $\begin{array}{c}\text { Height of the elbow } \\
\text { (cm)+Poplíteal } \\
\text { Height (cm) }\end{array}$ \\
\hline AGE & $\bar{X}$ & $\mathbf{S}$ & $\bar{X}$ & $\mathbf{S}$ & $\bar{X}$ & $\mathbf{S}$ & $\bar{X}$ & $\mathbf{S}$ & $\bar{X}$ & $\mathbf{S}$ & $\bar{X}$ & $\mathbf{S}$ \\
\hline $\mathbf{7}$ & $\mathbf{3 0 , 4 5}$ & $\pm 1,82$ & $\mathbf{3 0 , 7 5}$ & $\pm 1,79$ & $\mathbf{2 1 , 7 6}$ & $\pm 1,22$ & $\mathbf{7 , 6 2}$ & $\pm 0,69$ & $\mathbf{1 6 , 8 5}$ & $\pm 1,79$ & $\mathbf{4 6 , 1 7}$ & $\pm 2,63$ \\
$\mathbf{8}$ & $\mathbf{3 0 , 9 1}$ & $\pm 2,67$ & $\mathbf{3 1 , 1 1}$ & $\pm 2,16$ & $\mathbf{2 2 , 0 3}$ & $\pm 1,12$ & $\mathbf{7 , 9 7}$ & $\pm 0,66$ & $\mathbf{1 7 , 1 0}$ & $\pm 1,0$ & $\mathbf{4 7 , 2 3}$ & $\pm 2,12$ \\
$\mathbf{9}$ & $\mathbf{3 1 , 9 1}$ & $\pm 1,62$ & $\mathbf{3 3 , 0 6}$ & $\pm 1,72$ & $\mathbf{2 5 , 0 3}$ & $\pm 1,53$ & $\mathbf{8 , 5 0}$ & $\pm 0,91$ & $\mathbf{1 7 , 4 5}$ & $\pm 1,37$ & $\mathbf{4 8 , 9 2}$ & $\pm 1,95$ \\
$\mathbf{1 0}$ & $\mathbf{3 7 , 4 3}$ & $\pm 1,08$ & $\mathbf{3 7 , 3 5}$ & $\pm 1,85$ & $\mathbf{2 5 , 7 5}$ & $\pm 2,35$ & $\mathbf{9 , 7 5}$ & $\pm 0,67$ & $\mathbf{1 7 , 6 2}$ & $\pm 1,07$ & $\mathbf{5 4 , 3 0}$ & $\pm 2,11$ \\
$\mathbf{1 1}$ & $\mathbf{4 2 , 6 3}$ & $\pm 2,23$ & $\mathbf{4 1 , 7 2}$ & $\pm 3,47$ & $\mathbf{3 0 , 1 3}$ & $\pm 3,73$ & $\mathbf{1 0 , 8 3}$ & $\pm 0,71$ & $\mathbf{1 9 , 1 8}$ & $\pm 1,73$ & $\mathbf{6 1 , 3 3}$ & $\pm 3,43$ \\
$\mathbf{1 2}$ & $\mathbf{4 4 , 7 7}$ & $\pm 2,77$ & $\mathbf{4 1 , 9 6}$ & $\pm 2,76$ & $\mathbf{3 0 , 3 0}$ & $\pm 1,81$ & $\mathbf{1 1 , 5 8}$ & $\pm 1,47$ & $\mathbf{1 9 , 6 6}$ & $\pm 1,54$ & $\mathbf{6 4 , 5 6}$ & $\pm 4,08$ \\
$\mathbf{1 3}$ & $\mathbf{4 5 , 5 0}$ & $\pm 2,92$ & $\mathbf{4 3 , 2}$ & $\pm 2,17$ & $\mathbf{3 1 , 7 9}$ & $\pm 2,59$ & $\mathbf{1 2 , 3 2}$ & $\pm 0,83$ & $\mathbf{2 0 , 7 2}$ & $\pm 1,80$ & $\mathbf{6 7 , 1 4}$ & $\pm 3,59$ \\
$\mathbf{1 4}$ & $\mathbf{4 7 , 6 1}$ & $\pm 3,20$ & $\mathbf{4 6 , 6 8}$ & $\pm 2,58$ & $\mathbf{3 2 , 6 6}$ & $\pm 2,25$ & $\mathbf{1 2 , 6 0}$ & $\pm 1,01$ & $\mathbf{2 1 , 2 1}$ & $\pm 2,52$ & $\mathbf{6 8 , 4 3}$ & $\pm 4,27$ \\
$\mathbf{1 5}$ & $\mathbf{5 0 , 5 3}$ & $\pm 2,84$ & $\mathbf{4 7 , 3 8}$ & $\pm 3,70$ & $\mathbf{3 4 , 0 7}$ & $\pm 2,20$ & $\mathbf{1 2 , 7 2}$ & $\pm 1,64$ & $\mathbf{2 2 , 8}$ & $\pm 1,79$ & $\mathbf{7 2 , 9 3}$ & $\pm 3,74$ \\
$\mathbf{1 6}$ & $\mathbf{5 1 , 8 8}$ & $\pm 3,14$ & $\mathbf{5 0 , 5 0}$ & $\pm 2,58$ & $\mathbf{3 5 , 1 1}$ & $\pm 3,72$ & $\mathbf{1 3 , 9 1}$ & $\pm 0,91$ & $\mathbf{2 3 , 3 8}$ & $\pm 1,45$ & $\mathbf{7 5 , 3 8}$ & $\pm 4,47$ \\
$\mathbf{1 7}$ & $\mathbf{5 2 , 2 7}$ & $\pm 1,80$ & $\mathbf{5 1 , 0 3}$ & $\pm 2,09$ & $\mathbf{3 7 , 7 3}$ & $\pm 2,85$ & $\mathbf{1 4 , 5 3}$ & $\pm 0,98$ & $\mathbf{2 4 , 0 0}$ & $\pm 1,57$ & $\mathbf{7 5 , 8 3}$ & $\pm 3,24$ \\
\hline \hline
\end{tabular}

tant to support the lumbar spinal region in order to

In a school environment, when high desks are used, there will be no support for the feet, increasing the pressure on the popliteal vein and hips, forcing the knees to remain with excessive flexion, favoring the appearance of pain in feet, legs, knees and thighs. In this sense, it is important to warn for the indiscriminate use of the standard furniture, because this is not the ideal size for everyone, because each student has different anthropometric characteristics [7,18,36,37].

When the seat is too low, there is a decrease in knee flexion angle, forcing the trunk weight to the surface of the seat on its ischial tuberosities, reducing the contact with the thighs, increasing the intradiscal pressure, favoring the onset of discomfort and pain $[2,4,12,18,20,21,25,26,29,35,36]$. Thus, it is important to consider that the subject must sit down with knees bent at a right angle, with feet flat on the ground, so that the whole body weight is transferred to seat, floor, back rest and desk $[25,26,35,36]$. According to the posture adopted in the sitting position, there is a variation of the pelvis and consequent change in the configuration of the lumbar spine $[19,25,26,29,49]$. In this sense, all chairs need a suitable lumbar back rest, since this component is impordecrease discomfort generated by the intradiscal pressure characteristic of the sitting posture $[4,35,36]$.

For the age group from 7 to 10 years, the sacropopliteal length presented a difference of $28 \mathrm{~cm}$ for percentile 5 and $40 \mathrm{~cm}$ for percentile 95 , with a 12 $\mathrm{cm}$ difference in the age range from 7 to 9 years. In general, the variation in the sacro-popliteal length increased from $30.75 \mathrm{~cm}$ to $31.91 \mathrm{~cm}$, with a difference of only $1.16 \mathrm{~cm}$. However, for higher ages, which correspond to the growth spurt [45] for only one year, the value increased to $37.43 \mathrm{~cm}$, with an increase of $5.52 \mathrm{~cm}$.

The behavior of the sacro-popliteal variable for elementary school children (11 to 14 years) ranged from $41.72 \mathrm{~cm}$ to $46.68 \mathrm{~cm}$, with a difference of 4.96 $\mathrm{cm}$. For high school students (15 to 17 years), the average value of this variable ranged from $47.38 \mathrm{~cm}$ to $51.03 \mathrm{~cm}$, with a difference of $3.65 \mathrm{~cm}$. However, if the extremes of the table are compared (percentiles 5 and 95), the length variation found was $10.5 \mathrm{~cm}$.

Regarding the lumbar support height, in elementary school children (aged from 7 to 10 years), the values for extreme percentiles ranged from $14 \mathrm{~cm}$ to $19 \mathrm{~cm}$, with a difference of $5 \mathrm{~cm}$. However, taking 
the average variation, the lumbar support height ranged from $16.85 \mathrm{~cm}$ to $17.62 \mathrm{~cm}$, showing a change of only $0.77 \mathrm{~cm}$, and that in this age range, the trunk of these children barely increased, coinciding with the phase in which the child grows more in the lower limbs $[35,36,45]$. On the other hand, in the second cycle of basic education (children aged from 11 to 14 years), according to percentiles 5 and 95 , the lumbar support height ranged from $16 \mathrm{~cm}$ to $26 \mathrm{~cm}$, with a difference of $10 \mathrm{~cm}$, thus presenting a greater variation than children in the first cycle. Finally, high school students (adolescents aged from 15 to 17 years) had a variation of the lumbar support height from $20 \mathrm{~cm}$ to $27.5 \mathrm{~cm}$, with an increase of $7.5 \mathrm{~cm}$

The desk height was established by the sum of the popliteal height and the elbow height. At the age of 7 to 10 years, the desk height, proportional to age, ranged from $44 \mathrm{~cm}$ to $57 \mathrm{~cm}$, with an increase of 13 $\mathrm{cm}$; the average variation of the desk height ranged from $46.17 \mathrm{~cm} 54.30 \mathrm{~cm}$, indicating a growth of 8.13 $\mathrm{cm}$. However, in the age range from 11 to 14 years, the average desk height ranged from $61.33 \mathrm{~cm}$ to $68.43 \mathrm{~cm}$, with a growth of $7.16 \mathrm{~cm}$, whereas in the extremes, the growth was even more pronounced, ranging from $55 \mathrm{~cm}$ to $76 \mathrm{~cm}$, with a growth of 21 $\mathrm{cm}$, almost twice as the growth of the first cycle, confirming that at this phase, the child starts the growth spurt, a phase in which the seat height is no longer the most important factor, being the desk height the most important factor [35,36,45].

One of the major components that comprise the school furniture is the desk, as it is on its work surface that most school activities are held, especially reading and writing [45]. If the child sits at a height in which the desk plane is too high, there is a greater difficulty in performing his tasks, imposing a postural condition with exaggerated abduction of arms, which can provide the onset of diseases in the complex region of shoulders. The shoulder region is composed of a set of joints that work in harmony with the action of several muscles, tendons and ligaments. Thus, an inharmonious effort of these muscles will provide high mobilization of the humerus, which may cause injuries by impact, especially when the arms are working above the shoulder line $[8,35,36,42,44]$. The use of high desks will cause abduction, anterior flexion and elevation of shoulders, also influencing the neck posture, leading to fatigue of the muscles of shoulders and neck, causing a constant impact on the subacromial bursa, contributing in the emergence of pain, which may develop into an impingement syndrome $[5,8,19,30,32,41,42]$.
The coverage area of vision is very important for an adequate ergonomics. The distance from the ideal sight to the work surface should be approximately 40 $\mathrm{cm}$ without bending the trunk in order to obtain a $50 \%$ reduction in pressure of the intervertebral discs of the cervical spine $[4,25,26,35,36]$. If this distance is increased with the incorrect positioning of the furniture, the reading and writing activities will require the student to bend the trunk forward in an attempt to better fit the focus of his vision to books and / or exercise books. This stereotyped posture favors the onset of the pain process in the dorsal and cervical region $[1,5,8,14]$. To avoid this posture, the maximum angle recommended for the neck articulation should be between 20 to 30 degrees. However, for longer activities, up to 120 uninterrupted minutes, the ideal angle would be 15 degrees $[4,5,8,15,17,25,26,35,36,41,42]$.

School activities performed in the sitting position where the desk height is not compatible with the anthropometric characteristics of its user become a potential factor for noncompliance with the ideal angle of vision, disorganizing the correct postural alignment and favoring the occurrence of musculoskeletal discomfort in the cervical and lumbar spinal regions $[4,26,41]$. This knowledge can be confirmed with experimental procedures, monitoring the electromyographic signals of the neck muscles, combined with the application of subjective scales to assess body discomfort. The results show that the greater the head inclination angle, the greater the loss of strength of this muscle and, consequently, the higher the fatigue level [4,26].

\subsection{Body discomfort}

In the analysis of postural constraints, discomfort situations were found for first-grade children (Figure 2 ), especially for the gluteal region, back and shoulders. The seat-desk set seems to be the main problem, where for most students in early grades (children), it would be very high, while for those in higher grades (adolescents), it would be very low.

Comparing the data of the furniture used in schools and information recommended by the Brazilian Regulation Committee, which provides a type of school furniture for every age group, it was found that there is no match. Instead of furniture suiting its users, students, through awkward postures, try to adjust to the (unique) furniture (without criterion) adopted by schools [20,25,26,35,36]. 
Discomforts of the cervical and lumbar spinal regions were present in 17-year-old students mainly because the height of the desk surface is below the ideal, which forces the students to bend the head and trunk during activities such as reading and writing, which ends up by fatiguing the neck muscles in their role as head support and straining the lumbar spinal region due to its awkward position $[4,26]$.

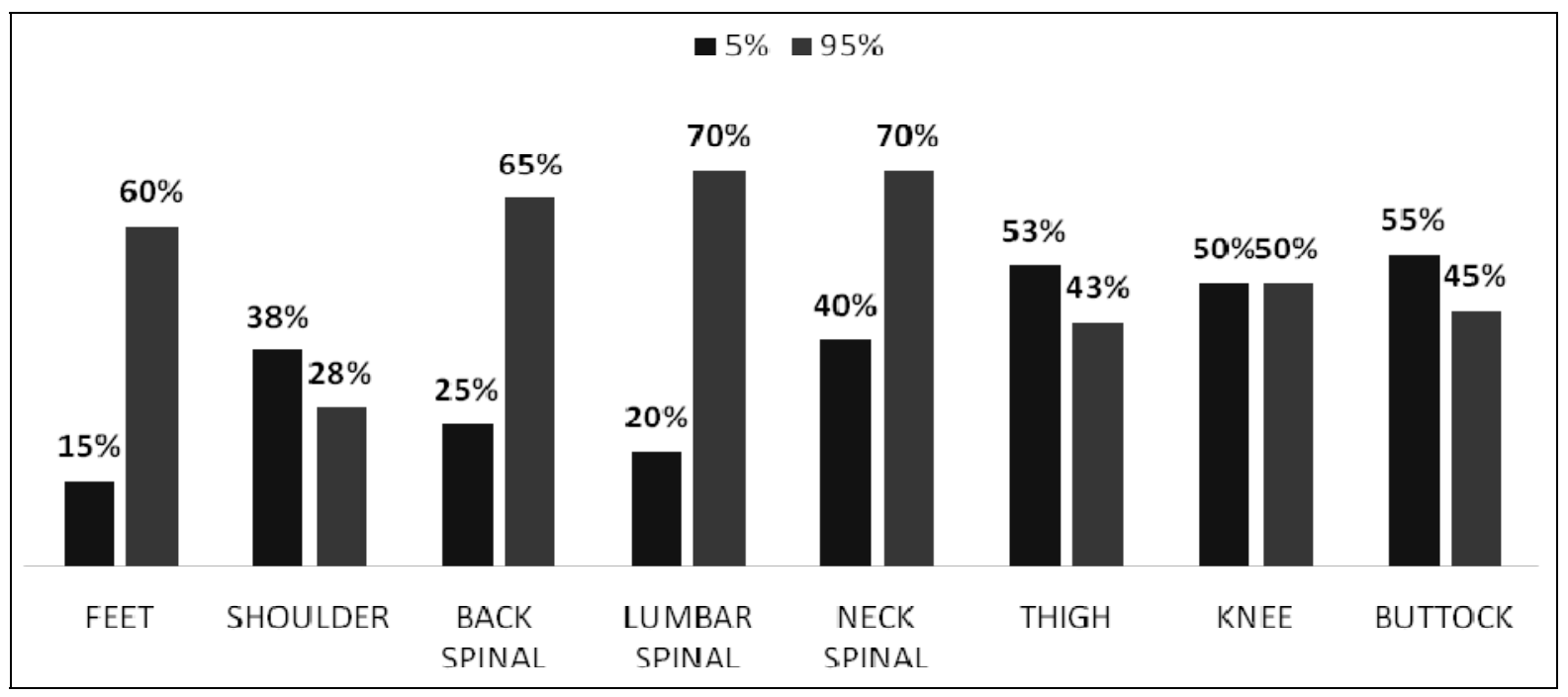

Fig. 2

Results of the postural discomfort assessment reported by schoolchildren, according to the percentile distribution.

Similarly, knee pain occurs because the seat in too low and favors the reduction of the joint angle, forcing the student to position his legs under the seat $[35,36]$. Otherwise, the elevation of the thigh causes a rotation of the pelvis backward, promotes an increase in pressure on the ischial tuberosities, bringing discomfort to buttock and lumbar spine regions $[4,26,35,36]$. Thus, to ease the constraints in the region of knees and buttocks, the ideal angle between thigh and leg should be 90 degrees $[4,20,25,26,35,36]$.

In an attempt to adapt to school furniture, small children are somehow trying to ease the constraints by frequently changing position. However, some situations are more critical, as in the case of very high chair that prevents smaller schoolchildren to support their feet on the ground. This situation is very inconvenient, because when the foot remains suspended, the thigh is pressed against the seat, making the normal venous return difficult, causing swelling in feet and pain in these regions [20,25,26,35,36].

For early school grades, the routine reading and writing activities are impaired because the desk is too high and the top is positioned on the horizontal line, forcing them to adopt stereotyped postures. Since the didactic material is too close to the eyes, there is a greater inclination of the head forward in search of better angle to focus on the study subject, which makes the adequate postural alignment difficult $[8,45]$. This fact is aggravated by forced abduction of the arms, when supported on the top table, causing discomfort in the shoulder girdle $[10,35,36]$. On the other hand, with 17-year-old adolescents the opposite occurs because the height of the desk work surface is too low, forcing them to adopt a stooped posture when approximating to the didactic material in order to better adequate their angle of vision. This posture causes the occurrence of musculoskeletal constraints in dorsal and cervical regions, contributing to the onset of painful processes $[4,20,25,26,35,36,42]$.

Regarding the use of lumbar support at the time of the achievements of school tasks, which are mainly reading and writing, it was found that although being so important for the relaxation of the column, it is not used, which may be contributing to the generation of back pain $[4,44]$. 7-year-old children cannot support 
their feet on the ground because the chair was too high and have to adapt to the furniture, sitting in the front of the seat and sometimes being on tiptoes to gain greater support, providing great discomfort in the regions the spine and knee joints and feet, according to their reports $[1-3,5,7,15,18,20,25,26,35,36]$.

\section{Conclusion}

Based on data found in this study, it could be inferred that the school furniture adopted by schools does not satisfactorily meet the students' needs, and are indicators of a number of problems related to body discomfort and low performance in school activities.

The differences between the smallest anthropometric measures (7-year-old children) and the highest measures (17-year-old adolescents) are significant, which would require furniture with dimensions suitable for each age group. Thus, the only type of furniture used by schools does not meet the dimensional demands of students. For some, the furniture is too large, and for others, too small. Children with heights at the extremities of the table (smaller and taller) experience constraints regarding the correct use of the furniture, which force them to adopt awkward postures. These data were based on a large number of body discomfort complaints that were reported by the schoolchildren evaluated.

It is expected that the anthropometric data collected in this study serve as parameters for the construction of school furniture more suitable for these age groups, and that the reported body discomfort serves as a warning to the Brazilian educational system to pay attention to this issue. Children and adolescents, regardless of their physical, mental and age state, should use the educational facilities with health, comfort and safety.

\section{References}

[1] G. Cardon, D. D. Clercq, I. D. Bourdeaudhuij and D. Breithecker, Sitting habits in elementary schoolchildren: a traditional versus a "Moving school",Patient Education and Counseling 54(2004), 133-142.

[2] J.A.O. Carneiro, L.M.Sousa, L.R.Munaro, Predominance the postural disorders in student of physical education of the Universidade Estadual do Sudoeste da Bahia, Revista Saúde Com. 2(2005), 118-123.

[3] J. Carvalho, Permanecer muito tempo sentado, Revista brasileira de atividade física e saúde, São Paulo 3(2007), 3233.
[4] D. Chaffin, G.B.J. Anderson and B.J.Martin, O Occupational Biomechanics, 4th Edition, New York: Jonh Wiley \& Sons, 2006, PP.376.

[5] A.L.Correa,J.S. Pereira, M.A.G.Silva, Evaluation of postural deviation in scholars: preliminary study, Fisioterapia Brasil 6(2005), 175-178.

[6] W. Dankaerts, et al., Differences in sitting postures are associated with nonspecific chronic low back pain disorders when patients are subclassified, Occupational Health/Ergonomics 31(2006), 698-704.

[7] C. Detsch, et al., Prevalence of postural changes in high school students in a city in southern Brazil, Rev Panam Salud Publica 21(2007), 231-238.

[8] A. Freudenthal, R.M.Van and J. Molembroek, J, The effect on sitting posture of a desk with a tem-degree inclination using an adjustable chair and table, Applied Ergonomics 22(1991), 329-336.

[9] D.L.Gallahue and J.C. Ozmun, Compreendendo o Desenvolvimento Motor: Bebês, Crianças, Adolescentes e

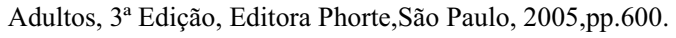

$[10] \mathrm{K}$. Grimmer and M.Williams, Gender-age environmental associates of adolescent low back pain, Appl. Ergon. 31(2000), 343-360.

[11]K. Grimmer, et al., Adolescent standing postural response to backpacks load: a randomised controlled experimental study, BMC Musculoskelet Disord. 10(2002), 1-10.

[12]B.M. Guimaraes, et al., Análise da carga de trabalho de analistas de sistemas e dos distúrbios osteomusculares, Fisioter. Mov. 24(2011), 115-124.

[13]C. Harris, L.Straker, C. Pollock and Sue Trinidad, Musculoskeletal outcomes in children using information technologythe need for a specific etiological model, International Journal of Industrial Ergonomics 35(2005), 131-138.

[14] J.A. Hansen, A Comparative Study of Three Different Kinds off Scholl Furniture, Ergonomics 38(1995), 1025-1035.

[15]D.S.Hira, An ergonomic appraisal of educational desks, Ergonomics 23(1980), 213-221.

[16]I. Iida, Ergonomia - Projeto e Produção. São Paulo: Edgard Blücher, 2005, pp.614.

[17]J. Iwamoto, H.Abe, Y.Tsukimura and Wakano, Relationship between radiographic abnormalities of lumbar spine and incidence of low back pain in high school rugby players: a prospective study, Scand. J Med. Sci. Sports 15(2005), 163-168.

[18]C.P. Joao, et al., The influence of different sitting postures on head/neck posture and muscle activity, Manual Therapy 15(2010), 54-60.

[19] A.I.Kapandji, Fisiologia Articular, $5^{\mathrm{a}}$ ed. São Paulo: Médica Pan-americana, 2000, pp.280.

[20]M.K. Leite, Espaço e o Mobiliário Escolar: Análise das atividades e tarefas realizadas em escolas estaduais do município de Bauru, Dissertação em Design. Faculdade de Arquitetura, Artes e Comunicação da Universidade Estadual Paulista Júlio de Mesquita Filho, Bauru, SP, 2008, pp.110.

[21] N.R.Marques, C.Z.Hallal, and M. Goncalves, Biomechanic, ergonomic, and clinical features of the sitting posture: a review, Fisioter. Pesq. 17(2010), 270-276.

[22]M. Marshall, A.C. Harrington and J.R Steele, Effect of work station design on sitting posture in young children, Ergonomics 38 (1995), 1932-1940.

[23]L. Martelli and J. Traebert, Descriptive study of backbonepostural changes in 10 to 16 year-old schoolchildren, TangaráSC, Brazil,2004, Revista Brasileira de Epidemiologia 9(2006), 87-93.

[24] M. Mokdad and M.Al-Ansari, Anthropometrics for the design of Bahraini school furniture. International Journal of Industrial Ergonomics 39(2009), 728-735. 
[25]A. R. P., Moro, Ergonomia da sala de aula: constrangimentos posturais impostos pelo mobiliário escolar, EFDeportes.com, Revista Digital. Buenos Aires 85(2005), 1-5.

[26]A.R.P.Moro, Análise biomecânica da postura sentada: uma abordagem ergonômica do mobiliário escolar. Tese de Doutorado, Santa Maria - Rio Grande do Sul, Universidade Federal de Santa Maria, 2000, pp.201.

[27] S. Murphy, P. Buckle and D. Stubbs, The use of the portable ergonomic observation method (PEO) to monitor the sitting posture of schoolchildren in the classroom, Applied Ergonomics 33(2002), 365-370.

[28]S. Murphy, P. Buckle and D. Stubbs, Classroom posture and self-reported back and neck pain in schoolchildren, Applied Ergonomics 35(2004), 113-120.

[29]P. B. O'Sullivan,et al., Effect of Different Upright Sitting Postures on Spinal-Pelvic Curvature and Trunk Muscle Activation in a Pain-Free Population, Occupational Health/Ergonomics 31(2006), E707-E712.

[30]H.W. Oxford, H. W, Anthropometric data for educational chairs, Ergonomics 12(1989), 38-46.

[31] S.A. Oyewole, J. M. Haight and A. Freivalds, The ergonomic design of classroom furniture/computer work station for first graders in the elementary school, International Journal of Industrial Ergonomics 40(2010), 437-447.

[32] G. Panagiotopoulou, K. Christoulas, A. Papanckolaou and K. Mandroukas, Classroom furniture dimensions and anthropometric measures in primary school, Applied Ergonomics 35(2004), 121-128.

[33]J. Panero and M. Zelnik, Las dimensiones humanas en los espacios interiores: estandares antropométricos, Barcelona, Gustavo Gili, $1^{\mathrm{a}}$ edição, $5^{\mathrm{a}}$ impressão, 2010, pp. 320

[34]L.M.Pereira, P.C.C Barros, M.N.D. Oliveira and A.R.Barbosa, Scoliosis: Screening in students from 10 to 15 years, Rev. Saúde Com. 2(2005), 134-43.

[35]P.F.Reis, Study of the Interface Pupil-Furniture: the Antropométrica and Biomechanic question of the Seated Position, Dissertação de mestrado em Engenharia de Produção - Ergonomia. UFSC, Florianópolis - SC, 2003, pp.106.

[36]P.F.Reis. Mobiliário Escolar: School Furniture: I study of the discomfort posture of scholars in the basic education, Dissertação de mestrado em Educação - Educação Física da UNICS, Palmas, PR, 2007, pp.100.

[37]C.R. Rodriguez-Añez, Anthropometry and it application in ergonomics, Revista Brasileira de Cineantropometria Desempenho Humano, Florianópolis 3(2001), 102-108.

[38]L. Saarni, et al., The Working Postures Among Schoolchildren-A Controlled Intervention Study on the Effects of Newly Designed Workstations, Journal of School Health 77(2007), 240-247.

[39]R.C Serrano. Novo equipamento de medições antropométricas. Ed. Rev. São Paulo-SP, Fundacentro, 1996.

[40]A.S.Silva, et al., The prevalence of alterations of positive for prescription of the of exercices in gymnastics academies, Rev. Saúde.Com. 1(2005), 124133.

[41]L. M. Straker, Neck/shoulder pain, habitual spinal posture and computer use in adolescents: the importance of gender, Ergonomics 54(2011), 539-546.

[42]L. Straker, R. Burgess-Limerick, C. Pollock and B. Maslen, The influence of desk and display design on posture and muscle activity variability whilst performing information technology tasks, Applied Ergonomics 40(2009), 852-859.

[43]P.B.Sukiennik, O aluno problema: transtornos emocionais de crianças e adolescentes, Editora Mercado Aberto, 2a Edição, Porto Alegre, RS, 2000, pp.475.
[44]M. Tunay and K. Melemez, An analysis of biomechanical and anthropometric parameters on classroom furniture design, African Journal of Biotechnology 7 (2008), 1081-1086.

[45]E. Viel and M. Esnault, Lombalgias e Cervicalgias da posição sentada, $1^{\mathrm{a}}$ edição, São Paulo, editora Manole, 2000, pp.163.

[46] J.R.Wilson, Fundamentals of Ergonomics in Theory and Practice, Applied Ergonomics 31(2000), 557-567.

[47]B. Yolandi, et al., The association between postural alignment and psychosocial factors to upper quadrant pain in high school students: A prospective study, Manual Therapy 14(2009), 647-653.

[48]A.R.Zapater, et al., A R. Seat posture: the efficiency of an educational program for scholars, Ciência Saúde Coletiva 9(2004), 191-199.

[49]A.M.B.Zeferino, et al., Monitoring growth.Jornal de Pediatria 79(2003), S23-S32, 2003. 